\title{
The Dynamics of Circuit of Culture Model in Promoting Angelina Jolie's Humanitarian Activities
}

\author{
Oluwadamilola Ayeni \\ Correspondence: Oluwadamilola Ayeni, Carnegie, 3163, VIC, Australia. \\ Received: June 11, 2018 \\ doi:10.11114/smc.v6i2.3493 \\ Accepted: July 23, $2018 \quad$ Online Published: July 29, 2018 \\ URL: https://doi.org/10.11114/smc.v6i2.3493
}

\begin{abstract}
This paper addresses the dynamics of Circuit of Culture model in relation to a celebrity's publicity efforts at promoting humanitarian activities. This analysis presents the publicity activities of Angelina Jolie using theoretical frameworks of the circuit of culture model which are; dynamics of representation, construction, consumption, identity and regulation. This paper presents several modes and points through which this model applies to her personality and humanitarian activities. This provides a description of how publicity works, thereby validating the importance of the model in the planning publicity activities for both individuals and organisations. The author conducts a case study using the method of content analysis and explores several academic literatures, texts, videos and media tools that demonstrates publicity activities by this celebrity.
\end{abstract}

This case study reveals that actions and activities embarked upon by Angelina Jolie depicts a clearer picture of how the circuit of culture model works. Each point on the model linking to one another and acting as tools to supporting the other.

Keywords: circuit of culture model, celebrity, humanitarian, publicity

\section{Introduction}

Theories are essential in understanding what we might consider as practices in any given field. In recent decades, celebrities are often used as attention magnets for several organizations to propagate change or promote their activities. Angelina Jolie is a perfect case study for this paper because of her active involvement in charity works globally, particularly in developing countries. Moreover, her identity as a wife, mother, and elite Hollywood actress makes her a natural fit to propagate some charitable activities.

This paper focuses exclusively on several aspects of her life, including activities, meetings, travels, and speeches, aimed at promoting and publicizing her humanitarian works. This analysis ties together the circuit of culture theory model and the publicity works. Her publicity works and activities will be analyzed alongside the model framework of representation, construction, consumption, identity and regulation. The ways through which this model applies to her personality and humanitarian activities will also be discussed.

Firstly, it is pertinent to provide a description of publicity and the recent developments with the use of celebrities in achieving it. Secondly, this paper will apply the Circuit of Culture model, to the promotional and publicity effort of Angelina Jolie. In addition, it will analyze several aspects of her activities that explains her efforts to create awareness for the plight of refugees. This will help guide a description of how the publicity works, and the interplay with the model of circuit and culture, thereby justifying the importance of the model in the planning publicity activities for both individuals and organization.

\subsection{Celebrity and Publicity}

Public relations as a profession is changing rapidly especially with the advancement in technology. "Public relation is a leadership and management function that helps achieve organizational objectives, define philosophy, and facilitate organizational change" (Lattimore et al. 2004, p. 5). Historically, not for profit organizations such as churches and charitable social organizations began the act of publicity since the early 20th century (Lattimore et al.2004, p. 26). The United Nations is an example of one organization that typically confers the title of "Goodwill Ambassador" on individuals who they consider are reputable with sufficient fan base to drive publicity goals. Considerably, this could explain why Angelina Jolie was appointed a Goodwill Ambassador and Messenger of Peace (Barron 2006). While considering that this is an ever-growing initiative by organizations, the question is why involve celebrities? Moreover, 
considering the whole aim and gain in the humanitarian cause, are celebrities capable of creating enough awareness to get relevant authorities to force a policy change? The answer to this is yes.

\subsection{Celebrities and Humanitarian Initiatives in Contemporary Society}

Asides organizations conferring goodwill ambassador titles and involving celebrities for humanitarian and charitable causes, celebrities have plunged on this cause and mantle for promoting change. In 2017 after the hurricane Harvey hit Houston, US, celebrities as Kevin Hart, Justin Timberlake, Kim Kardashian, Dwayne Johnson, Sandra Bullock, Tyler Perry, DJ Khaled donated money to those affected by this disaster. Kevin Hart kicked off his donation by introdroducing the hurricane Harvey Relief Challenge and announced his proposed donation on his Instagram page. He posted a video which challenged his famous friends into following this path to help relief those in need. The challenge continued, and several celebrities joined by donating huge sum of money to several charitable organizations and fund accounts to relief those affected by the disaster (Rubin 2017). Most, if not these celebrities involved, communicated their initiatives and charitable acts on their social media account through videos and posts. Those actions created a widespread involvement and publicity in this area. In contemporary society, it is not new that celebrities are continuously publicizing their participation and deeds in charitable and humanitarian causes. Several celebrities have created charity organizations and constantly promote these actions through their social media accounts, media conferences, briefings and the press. Celebrities like Lady Gaga, have used her vast online fan base and influence to mobilize fans to be engaged in activist causes. A research conducted by Click, Lee \&Wilson (2017) shows that Lady Gaga's fans are deeply trusting of her political values and actions. What this creates is a community of fans who have a positive attitude towards activism.

In the views of Huliaras and Tzifakis (2010), celebrities are reputable enough to get media attention in ways that can increase public awareness, and in turn, get the attention of not just their audience but the high levels of government. Wheeler (2011) adds that, these celebrities are perceived by societies to be credible with distinctive personality traits and expressed words that can elicit a desired change. However, despite the growing attention of celebrities as humanitarian activists, there have been criticisms viciously by some scholars that these celebrities are mere public-seeking, hypocrites and being ignorant of several societal issues (Dieter \& Kumar 2008). However, despite the debates in this area, this paper will focus on the "light" which is the publicity efforts at humanitarian activities and how it relates to the circuit of culture model.

\subsection{The Circuit of Culture Model}

The circuit of culture is a foundation for developing theory on public relations that enlightens relevant practices globally (Curtin and Gaither, 2005). The effect is that it creates a platform to which the practice of publicity can thrive. A platform that allows for individuals as well as organizations to act as cultural intermediaries in a larger cultural economy. According to Du Gay et al. (1997), the model comprises of several moments (parts) that overlap in meanings and interpretations. They also work together to give a whole meaning of publicity framework. Also, they add that the model is not a linear one-way dimension to understanding the process of publicity. What matters the most is to move in a pattern that allows for each part of the circuit to be related in the next part. It is a model that best explains the act of publicity in its dynamic nature. A brief description of each moment in the model is essential in understanding the basis for this argument.

Representation means making sense of things and situations by the way it is represented. This implies that meanings can be derived from a concept because of how they are presented (Hall 1997). Meanings helps to make sense of new events or unexperienced situations. In this way, use of words, images, description that are familiar to the audience gives meanings to a cause. As a result, making sense of the reality through words and images expressed in representation follows (du Gay et al. 1997).

Production is the approach through which ideas are presented, i.e. the logistical approach to representation (Curtin \& Gaither 2005). They add that the process of production does not come into reality without consumption. Consumption are anticipated meanings during production which cannot transpire without the need for 'consumption' (Mackay 1997). In this vein, 'consumption' means the audience for which the production is intended. Similarly, this involves monitoring how the audience for which the production is designed reacts to the representation.

Identity are meanings given to a cause through the process of representation, production and consumption. Identities are broad and could mean the personality traits of the celebrity that explains why they choose to represent or produce contents for their target audience (Curtin \& Gaither 2005).

Regulation are meanings derived from the entire process of representation, production, consumption, and personal identity that could be aimed at campaigning for a cause. It could be for a policy change, humanitarian act or to change some governmental conventions that are not suitable for those who consume the production (Curtin \& Gaither 2005). 


\section{Method}

The main objective of this paper is to analyze the circuit of culture theory model in application to Angelina Jolie's Publicity efforts using a qualitative descriptive/ content analysis research methodology. This technique is very vital and crucial to analysing and interpreting any given data/resource. This method of data collections explores several phenomenon, circumstances, beliefs, actions and quotes or beliefs (Patton, 2002). Rather than analysing numerical data, these methods utilise linguistic texts. Content analysis will be utilised to gather details, facts, texts and several information relating to publicity efforts utilised by the celebrity. This is one important method in qualitative research deployed by the author as it analyses literatures and texts from communication materials such as books, videos, research articles and materials that will evolve into discussion and conclusions. Materials analysed for this article originates mainly from the publicity materials of the Angelina Jolie, UNCHR posts, news articles and reports and academic journal articles.

This paper addresses many topics such as the circuit of culture model of publicity. It also explores the role of celebrities and their participation in humanitarian activities. Whilst doing so, it focuses fairly on publicity efforts by Angelina Jolie, a humanitarian. This attempt was implemented to analyse, and then connect the Circuit of Culture model with a practical example of publicity efforts. This paper will serve as a resource and guide for organizations and individuals who desire to embark on a publicity process. This paper may also serve as a guide to students and scholars into understanding the model in application to real examples.

\subsection{Angelina Jolie's Humanitarian Efforts and the Circuit of Culture Model.}

Angelina Jolie, a Hollywood actress in her early thirties, had featured in more than forty films. Her road to humanitarian acts did not just start from being a UN Ambassador for Peace, but also can be seen from her personal take to caring for refugees. Her appointment and the adoption of her son Maddox, a Cambodian citizen is evident that her humanitarian activities are fueled in her personal representation (McHugh 2014). She has been a huge success as a publicity agent for the United Nations.

It all started in Cambodia during a shoot of the popular adventure movie Tom Raider. Angelina Jolie was chosen as a lead actress to play the role of Lara Croft and this movie was filmed in Angkor, Cambodia (La Bella, 2009). Jolie was stunned that the locations of the movie shoot were restricted to some parts of the country. This was due to land mines that could be triggered because of human or vehicular activities on the ground in these parts of the country (La Bella, 2009). She was astounded that some areas in that country had not been de-mined and this experience prompted her special interest in the country (La Bella 2009). The event that followed was her meeting with officials of United Nations High commissioner for Refugees (UNHCR) in Washington D.C. to increase her knowledge about Cambodia (McHugh 2014). Jolie's decision to learn more about refugees' camps coupled with the UNHCR, mission made it a platform for her to achieve her goals.

In relation to the circuit of culture model, it is evident that Jolie's in her quest to know more, sought further information on living conditions in Cambodia. Her words: "And to know that there are hospitals where kids are still being affected by stepping on landmines every day, was horrifying and so sad. You never hear about that. To discover that kind of stuff was to really understand people in the rest of the world" (La Bella 2009, p. 10). This statement shows a great deal about her identity and personality. Her caring nature prompted her to resort to platforms in which she can best make meanings out of the sad situation. Her desire to learn about these refugee camps shows how interested she is in campaigning for a good and hospitable situation in Cambodia.

\subsection{Published Book: Notes from my Travels: Visits with Refugees in Africa, Cambodia, Pakistan and Ecuador}

In February 2001, the UNHCR called for Jolie to join some other field workers to visit some refugee camps in selected countries part of which were Sierra Leone and Tanzania. This actress in 2003, published a book titled Notes from my Travels: Visits with Refugees in Africa, Cambodia, Pakistan and Ecuador. These notes included her interests and the reasons she chose to embark on these trips. It also highlighted her daily travails in the humanitarian mission.

According to the circuit of culture model, this book is a representation of Angelina Jolie's passion for her humanitarian cause. Here, it is evident that Jolie who is the producer encodes her messages through set of meanings that she identifies with and meanings she represents through the languages used. According to Don Mills' (2006) article in National Post, Angelina Jolie put up this book to raise money for refugees in Chile. Barron (2009) also expresses his thoughts on Jolie's books as he mentions that it reveals testaments of her experiences as she moved out of her Hollywood comfort zone into the lives of refugees. Jolie may not be considered a professional travel writer, but this notes she had on her trip to those countries possesses a platform through which she could raise awareness of some remote countries that were unknown to her (Barron 2009). This highlights her personal commitment to helping the displaced refugees in those countries. 
Her book reveals her growing determination and enthusiasm as a humanitarian activist. This book can be used as a strong argument in understanding the circuit of culture model in relation to her humanitarian activities. The book represents production in the sense that she utilized a literary form to convey her message across to the relevant authorities. She empathetically narrated the poor living conditions of refugees (consumers) in other to arouse the interests of the intended audience and those in charge of regulations. Also, it is important to add that in the first section of her book, Jolie made some statements that are essential in understanding the concept of identity and representation in the circuit of culture model. '...No, just an American who wants to learn about Africa' (Barron 2009 p. 217) represents many other westerners who are uninformed about some issues facing countries in Africa and their inquisitiveness about it. The phrase 'I am on a plane to Africa'. (Barron 2009 p. 217) is also typical of many other westerners who address Africa as a country rather than a continent. These statements connote meanings that links who she is as a westerner to the point of creating awareness of issues facing countries in Africa

\subsection{Angelina Jolie's Uses Speeches to Address the International Audience}

\subsubsection{Jolie Speech on World Refugee Day}

Jolie commemorated the world refugee day with the Syrian refugees in Turkey. Turkey is identified as one of the largest refuge-hosting nations. In Turkey, she made a very powerful and memorable call for action in other to support these refugees. In her statement, she mentioned that the world has never been so wealthy, yet, there are more people with displaced homes, impoverished and are ripped of their basic needs (UNHCFR 2015a). In her speech, she stated that refugees are not people looking to migrate for economic reasons but are those running to find a place to live. They are displaced and are running out of options on where to go for safety (Jolie Pitt \& Helic 2015). She makes a very remarkable statement in her speech that advocates for the welfare of the refugees. This is because they are the future of the countries that are being overly protective (UNHCFR 2015b). Her words are very empathetic. She was charging the host country to keep up the good cause of helping these refugees. Also, she pleads with the international community to recognize that World Refugee as a day to face the truths about international crisis (Tawfeeq 2012).

This speech in relation to the circuit of culture model is directed towards her quest to make conducive environment for the refugees. This environment in which she finds herself has shaped her identity and personality and this translates to why she makes this call. The speech is a produced content with objects that are encoded to represent meanings in other to propagate a change. Hopefully, these messages she communicates gets recognized enough to make a change. Her final words rather intriguing was that 'I call, again, on the United Nations Security Council: Send your ministers and ambassadors here. Witness this crisis for yourself. See that it simply cannot go on. And that it is past time for a credible plan to reach a political solution to end the conflict' (UNHCR 2015a).

\subsubsection{Angelina Jolie's Speech at the Jean Hersholt Humanitarian Award}

In 2013, Angelina Jolie received the Jean Hersholt Humanitarian Award. During her acceptance speech, her representation of a mother, a celebrity and one who identifies with refugees were displayed. She gave honor to her mother who died of ovarian cancer and owed her humanitarian endeavors to her late mother who is a source of inspiration. She mentions that her mother urged her to live a life of use to others and that has been her motivation towards her humanitarian acts (France 2013). She spoke on how her trips to these refugee countries had impacted her, and with a cracking voice, adds that "we are all, everyone in this room, so fortunate." (France 2013, para 8). She was puzzled on how she never understood how people are lucky to be born with chances and how a woman just like her who had chances to be great was lying in refugee camps with no voice (Divers 2013). She uttered a few words in her speech to her son Maddox and how his support enables her to achieve all she does. She further stated that "Mad, I'm not going to cry, I promise," she said. "I'm not going to embarrass you. You and your brothers and sisters are my happiness. There is no greater honor than being your mother." (France 2013, para 10). Maddox is one of the first of Jolie's adopted children from a refugee camp in Cambodia. His adoption according to McHugh (2014) marked an increase in Jolie's self-identity.

Jolie emotionally expressed pain, rejection of these refugees through the choice of words and how she creates images from the message. She identifies as an individual and represents not just a celebrity, but a mother who has so much love for a nation and a mother who takes prides in her children. It is evident that the identity of Jolie as a public figure directly interacts with her messages and presents them through her speeches in ways that creates awareness about her humanitarian act and her personality. At the same time, Jolie had captured the attention of her audience by particularly emphasizing on her personal life relating it with her ambitions and passion. In her case, her private life and experiences transcends more to achieving a global cause and propagating policy change.

\subsection{Angelina Jolie at Meetings and Conferences}

Angelina Jolie also had met with the Secretary of State John Kerry when she visited the US State Department in 
Washington DC. Kerry commended Jolie on her enthusiasm and dedication towards the refugee crises facing the world. She responded that the world leaders should adopt new ways towards assisting with aids to settle the displaced refugees. She added that there should be focus on new leadership with innovative solutions to the crises (Fishel 2016).

Again, she shows how this model interacts. It shows the inter activity that occurs between production, identity and regulation and explains the dangers according to Curtin and Gaither (2005) inherent in isolating one moment in the model. Regulation is a process that emanates from the interaction between production, consumption, representation and identity. It involves the use of structured messages that aids in producing the accurate and strategic content to the target authority. Jolie exemplifies this model through her response to John Kerry. Her focus was displayed through her quest for a change in policy that affects the refugees.

The UN Security council had her 7433rd meeting in New York and Jolie made strategic efforts to reach the audience (UN Security Council) to raise awareness on the ongoing refugee crises in Syria. Her representation of the refugee crisis was used in empathetic, emotional and persuasive words she expressed while conveying her message. She stated her wishes were that the Syrian families she visited could be at the briefing as she believed that those refugees would be in the best position to express their feelings (UNHCR 2015b). She expressed her dis pleasure at the UN in failing at discharging such their duties in Syria. She also states that the 'International humanitarian law prohibits torture, starvation, the targeting of schools and hospitals - but these crimes are happening every day in Syria.' (UNHCR 2015b, para. 14). Here, she urges the Security Council to use its powers to address the crimes that threatens the peace of the Syrians.

This representative language and tone shapes the messages she was conveying to her consumers (the audience). Her identity and the identities of the audience of this speech are similar and that aids to propagate the direct assistance she requires form the Security Council. Also, she mentions that the purpose of the UN is to prevent and end conflicts as they arise and to provide solutions that help save lives of those who are affected by these conflicts. Jolie's actions are embodied to draw attention to her feminine representations of issues in ways that her gender and sexuality ae used to make meanings in her messages. She wants the Security Council to own up its responsibility as she calls member states to prepare in making Syrian women represented in peace negotiations (UNHCR 2015b).

\subsection{Angelina Jolie Writes an Open Editorial}

Jolie's emotional reactions towards finding a better life for the refugees motivated her to writing an open editorial in the Washingon Post about Dafur and its crises (Wheeler 2011). Her post about Dafur and neighboring villages reveals in her opinions the need for justice. She expresses so much fear for those living in Dafur especially for the mothers and children. Mothers were gang raped. She was saddened that the International Criminal Court (ICC) have prohibited the UN peacekeepers from reaching Dafur as it keeps those living in the nearby camps at greater risk (Jolie 2007). Jolie's direct representation and understanding of crises in Dafur is expressed in the editorial as she was concerned most especially about the mothers and children who she believes are more vulnerable. This editorial is a platform that aids in her publicity efforts. It also demonstrates how her identity relates with the representation of issues in Dafur. This evidently was communicated tool through the editorial to create awareness and propagating her desired change.

\subsection{Documentary Videos}

The UNCHR published a documentary video about Angelina Jolie's humanitarian visit to Azraq camp for refugees in Jordan. Before analyzing the documentary, it is important to note that the video was filmed and recorded in Jolie's voice. The tone of voice used is very subtle and calm. In the video, she sounded terrified that the Syrian conflicts was in its sixth year. She visited the home of Hameed, a refugee and his wife and four daughters who had been living in the camp since June 2016. She inquired about their journey to Jordan and they mentioned that after they were displaced in Syria, it took them four years to travel to find refuge. The wife of Hameed revealed, that she desired a home for her children to feel safe after the war. She narrated that life in the camp is very static and there are children who knew no other life than living in the dessert under harsh conditions (UNCHR 2016a).

Also, another video, records how Angelina Jolie is seen giving hopes to a young girl refugee named Leemar in the refugee camp. A bomb destroyed their family home in Syria. They fled to Jordan, but hardship took them back to Syria. Leemar's brother died in the attack that day. Both of Leemar's legs were shattered by the bombs. She could not get medical treatment until she arrived in Jordan. Her hopes are that when she gets out of the hospital she was going to wear a dress and walk on heels. Video showed Jolie hugging this girl and this revealed how emotionally moved she is as a mother (UNCHR 2016b). This documentary placed her humanitarian work which is a point in fund raising for her concerns and as an individual, mother and humanitarian. In the same vein, her representation of the Syrian refugees living in Azraq, Jolie gave albeit a personalized view about a public concern (consumers), to the desired authority (regulation) using a documentary video (production). Her accounts of the situation in this camp explicitly invites a global awareness to living conditions of the refugees in Azraq, Jordan. 


\subsection{Movie Production}

Another initiative by Angelina Jolie in a long-time activism is her attempt at directing the film: In the Land of Blood and Honey. The movie narrates the plights of a Serbian solider and a Muslim woman after the occurrence of the Bosnian war. This film brings to light the viciousness of the war and rape of women in the camps around Bosnia (Borger 2012). Angelina Jolie claims that this film was created to show the true story of those who experienced the war.

Phil Harding (2009) explains several factors and approaches celebrities use to assume roles in contemporary society. Their participation in humanitarian initiatives leads as a guide to showcase unfamiliar places and struggles to the international audience. This tool in reaching out to the international audience through several publicities plugs such as words, images and descriptions is a classic example of representation in the circuit of culture model. In representation, words, images, description gives meanings to the international audience who might be initially less involved with those societies. According to Chouliaraki (2012) the celebrity's narration and personal testimony of the suffering of others in these affected societies can go a long way in propagating initiatives. This all adds up to what can be considered a perfect fit for understanding the circuit of culture model.

\section{Discussion}

The role of celebrities in modern society have evolved and have been a growing phenomenon. Several celebrities have been involved in good causes and humanitarian initiatives. Some have gone as far as setting up charity organisations or partnership with charity organisations. All these acts are in fact perceived by many as methods of creating publicity on the part of the celebrities.

Revisiting the dynamics of the model, what this paper has been able to do is to bring this model into the light of the publicity. Representation as depicted from several humanitarian initiatives shows examples of the way words, images and familiar text are circumstances are portrayed by these celebrities to communicate and give meanings to their publicized initiatives. Production is the act of logistically putting works to creating the process of publicity for consumption. Consumption from this case study means the audience for which the production is intended. Identity is meanings. They are broad definition of a publicity initiative and could mean the personality traits of the celebrity that explains why they choose to represent or produce contents for their target audience (Curtin \& Gaither 2005). Every publicity efforts starts with the end in mind the aim for embarking upon such initiatives is regulation. Regulation in this model answers the whole question on why the publicity was indented. The publicity process should be a whole moment in the circuit. Although, each moment in the circuit of culture draws for itself specific meanings, these meanings should be an ongoing process for the general goal of publicity. This successfully proves that publicity is not a ritualistic activity, rather a set of logical process flow that can be supported using this circuit of culture model.

\section{Conclusion}

In highlighting humanitarian activities of a Hollywood celebrity Angelina Jolie, this paper explored how these activities fit into the circuit of culture model of public relations. The model as explained in this essay reveals a lot about organizational and individual publicity efforts. The aim was to set up a case study of how an individual (Hollywood celebrity) publicize herself by engaging in a humanitarian cause. This essay explored Angelina Jolie's activities to illustrate concepts that are essential in publicity. It best explains the circuit of culture theory model and offers a clearer picture of how this model can be applied to real activities. In addition, one may argue that this model is very dynamic, and all the moments are very essential.

Also, as evident in this paper, words as a form of representation is obvious in all the production tools deployed by this celebrity. Her words paint pictures and create image in the minds of her consumers. It shapes the way thoughts are provoked and this aids in effective publicity. What she does here gives a clear approach to how effectively this model works on an individual's effort to creating awareness for a global cause. From her published book, to her speeches at award ceremonies, to meetings she had, to visits at refugee camps. All the actions by this Hollywood celebrity depicts a clearer picture of how the model works. Each point on the model links to one another and her helpful to achieving the other.

Although celebrities have been criticized on the motives for engaging in humanitarian activities, what we see in the case of Angelina Jolie is activism for a positive cause. Whatever be the interests inherent in the minds of the celebrities, the involvement of Angelina Jolie in her humanitarian causes is to create a better environment for refugees. Through the messages and the platform utilised, and the awareness created towards this cause, it appears to have contributed to raising public awareness on an international level. Barnes (2008, cited in McHugh 2014) adds that Jolie does not employ the services of a publicist, rather attributes her success in public image to herself, her manager and her partner Brad Pitt. However, her capability in taking up such responsibilities and controlling her identity as a celebrity and responsibility for publicizing her own activities is commendable. Overall, the results from this analysis depicts that 
celebrities are generally effective in terms of publicly creating awareness of societal issues to the international audience. These efforts have a way of bringing the sufferings of those in distant places, narrating and describing those using images, texts and familiar objects and this in turn creates a clear reflection of situation and condition in these places.

\section{Recommendation}

This paper has proved that there is a direct link between the circuit of culture model of publicity and the use of celebrities as attention magnets for propagating social causes. However, research is scarce in areas of celebrity involvement in humanitarian and charitable social cause especially in contemporary society. Although the results of this paper proved the link and relationship between the model and a case study (Angelina Jolie), more research should be conducted using a wider celebrity base to gauge the functionality, application and relevance of the model in contemporary society.

\section{References}

Barron, L. (2009). An actress compelled to act: Angelina Jolie's notes from my travels as celebrity activist/travel narrative, Postcolonial Studies, 12(2), 211-228. https://doi.org/10.1080/13688790902887189

Borger, J. (2012). Angelina Jolie receives threats over in the land of blood and honey. The Guardian [online]. Available from: http://www.guardian.co.uk/world/2012/feb/15/angelina-jolie-threats- land-of-blood-and-honey [Accessed 15 February 2012.

Chouliaraki, L. (2012). The theatricality of humanitarianism: A critique of celebrity advocacy. Communication and Critical/Cultural Studies, 9(1), 1-21. https://doi.org/10.1080/14791420.2011.637055

Click, M. A., Lee, H., \& Holladay, H. W. (2017). 'You're born to be brave': Lady Gaga's use of social media to inspire fans' political awareness. International Journal of Cultural Studies, 20(6), 603-619. https://doi.org/10.1177/1367877915595893

Curtin, P. A., \& Gaither, T. K. (2005). Privileging identity, difference, and power: The Circuit of Culture as a basis for public relations theory, Journal of Public Relations Research, 17(2), 91-115. https://doi.org/10.1207/s1532754xjprr1702_3

Dieter, H., \& Kumar, R. (2008). The downside of celebrity diplomacy: The neglected complexity of development. Global Governance, 14(3), 259-264.

Don Mills', O. (2006). Angelina Jolie auctioning her journal to raise money for refugees in Chile, National Post, 22 June, 2006 (online ProQuest)

Du Gay, P., Hall, S., Janes, L., Madsen, A. K., Mackay, H., \& Negus, K. (2013). Doing cultural studies: The story of the Sony Walkman. Sage.

Fishel, J. (2016). Angelina Jolie calls for "New Approach' to address global refugee crisis, ABC News, retrieved from http://abcnews.go.com/International/angelina-jolie-calls-approach-address-global-refugee-crisis/story?id=4000270 4

France, L. R. (2013). Angelina Jolie's emotional acceptance speech at Governors Awards, CNN, retrieved from http://edition.cnn.com/2013/11/18/showbiz/celebrity-news-gossip/angelina-jolie-governors-awards/

Hall, S. (1997). Introduction' in S Hall (ed.), Representation: Cultural representations and signifying practices, Sage, Thousand Oaks, 1-11. https://doi.org/10.4324/9780203449561_chapter_1

Harding, P. (2009). The great global switch-off: International coverage in UK public service broadcasting. London, Oxfam, Polis, International Broadcasting Trust.

Huliaras, A., \& Tzifakis, N. (2010). Celebrity Activism in International Relations: In Search of a Framework for Analysis, Global Society, 24(2), 55-274. https://doi.org/10.1080/13600821003626567

Jolie, A. (2007). Justice for Dafur' The Washington Post company, retrieved from http://www.washingtonpost.com/wpdyn/content/article/2007/02/27/AR2007022701161.html

Jolie, P. A., \& Helic, A. (2015). Don’t blame refugees for seeking a better life, The Times, retrieved from http://www.thetimes.co.uk/tto/public/article4549225.ece

La Bella, L. (2009). Angelina Jolie: Goodwill Ambassador for the United Nations. New York: The Rosen Publishing Group Inc.

Lattimore, D., Baskin, O., Heiman, S. T., Toth, E. L, \& Leuven, V. (2004). Public Relations, the Profession and the practice, New York: McGraw Hill. 
Mackay, H. (1997). Introduction', in H Mackay(ed.), Consumption and everyday life, Thousand Oaks: Sage, 1-12. https://doi.org/10.1017/CBO9780511518270.001

McHugh, K. (2014). Of agency and embodiment: Angelina Jolie's autographic transformations, Celebrity Studies, 5(1-2), 5-19. https://doi.org/10.1080/19392397.2014.887531

Patton, M. Q. (2002). Qualitative research \& evaluation methods, 3rd ed, Thousand Oaks, CA: Sage Publications.

Rubin, R. (2017). Hurricane Harvey: Leonardo DiCaprio, Sandra Bullock, Tyler Perry and Others Donate to Relief Efforts, retrieved from

https://variety.com/2017/biz/news/hurricane-harvey-celebrity-donations-reactions-kevin-hart-chris-young-1202540 543/ August 28, 2017

Tawfeeq, M. (2012). US envoy Angelina Jolie visits Syria refugees in Iraq , CNN. retrieved from, http://www.cnn.com/2012/09/15/world/meast/iraq-syria-angelina-jolie

UNCHR (2016a). Angelina Jolie Pitt with Syrian refugees in Jordan, retrieved from http://www.unhcr.org/en-au/news/videos/2016/10/580e48894/angelina-jolie-pitt-with-syrian-refugees-in-jordan.ht $\mathrm{ml}$

UNCHR (2016b). Angelina Jolie Pitt gives hope to refugee Leemar in Jordan's Azraq camp, retrieved from http://www.unhcr.org/en-au/news/videos/2016/10/580e34464/angelina-jolie-pitt-gives-hope-to-refugee-leemar-in-j ordans-azraq-camp.html

UNHCR (2015a). UNHCR Special Envoy Angelina Jolie Pitt calls for action on World Refugee Day', retrieved from, http://www.unhcr.org/news/press/2015/6/558595e96/unhcr-special-envoy-angelina-jolie-pitt-calls-action-world-ref ugee-day.html

UNHCR (2015b). Angelina Jolie Pitt's Speech to the UN Security Council retrieved from http://www.unrefugees.org/2015/04/angelina-jolies-speech-to-the-un-security-council/

Wheeler, M. (2011). Celebrity diplomacy: United Nations' Goodwill Ambassadors and Messengers of Peace, Celebrity Studies, 2(1), 6-18. https://doi.org/10.1080/19392397.2011.543267

\section{Copyrights}

Copyright for this article is retained by the author(s), with first publication rights granted to the journal.

This is an open-access article distributed under the terms and conditions of the Creative Commons Attribution license which permits unrestricted use, distribution, and reproduction in any medium, provided the original work is properly cited. 